\title{
Probing DNA Polymerase Function with Synthetic Nucleotides
}

\author{
Andreas Marx, * Ilka Detmer, Jens Gaster, Daniel Summerer \\ Kekulé-Institut für Organische Chemie und Biochemie, Universität Bonn, Gerhard-Domagk-Str. 1, 53121 Bonn, Germany \\ Fax +49(228)735388; E-mail: a.marx@uni-bonn.de
}

\begin{abstract}
Transmission of the genetic information from the parental DNA strand to the offspring is crucial for the survival of any living species. In nature this process is catalyzed by the replication machinery in which DNA polymerases are essential for the entire DNA synthesis. Recently, a wealth of valuable new insights into DNA polymerase mechanisms were gained through application of carefully designed synthetic nucleotides and oligonucleotides in functional enzyme studies. The applied analogues exhibit features that differ in certain aspects from their natural counterparts and thus, allow investigation of the involvement and efficacy of a chosen particular aspect on the entire complex enzyme mechanism. This review will focus on a depiction of the synthetic efforts that were undertaken towards the targeted synthesis of nucleotide analogues with carefully altered properties. The synthetic endeavors will be discussed in the context of the motivation and the problem under investigation.

1 Introduction

2 Functional DNA Polymerase Studies

3 Modified Substrates for Investigation of DNA Polymerase Function

3.1 Nucleobase Modifications

3.1.1 Rearrangement of Nucleobase Hydrogen Bonding Patterns

3.1.2 Deleting Nucleobase Hydrogen Bonding Acceptors and/or Donors

3.1.3 Non-Nucleoside Surrogates

3.2 Modification at the 2 -Deoxyribose Moiety

4 Outlook
\end{abstract}

Key words: DNA, nucleosides, nucleotides, oligonucleotides, DNA polymerases

\section{$1 \quad$ Introduction}

Transmission of the genetic information from the parental DNA strand to the offspring is crucial for the survival of any living species. In nature this process is catalyzed by the replication machinery in which DNA polymerases are essential for the entire DNA synthesis. ${ }^{1}$ DNA polymerases catalyze proceeding DNA synthesis in a template-directed manner (Figure 1). All common DNA polymerases require a short DNA strand hybridized to the template strand to serve as a primer for initiation of DNA synthesis. Proceeding DNA synthesis is promoted by DNA polymerases through catalysis of nucleophilic attack of the 3'hydroxyl group of the 3 -terminal nucleotide at the primer strand to the $\alpha$-phosphate of an incoming $2^{\prime}$-deoxynucleoside-5'-O-triphosphate (dNTP) leading to substitution of pyrophosphate (Figure 1). ${ }^{2}$ This phosphoryl transfer step is believed to be promoted by two magnesium ions that stabilize a penta-coordinated transition state through complexation of the phosphate groups and essential carboxylate moieties on the active site.

The nature of DNA replication fidelity according to the Watson-Crick rule is of immense biological importance due to the fundamental requirement for accurate DNA synthesis, in both replicative and repair processes. All DNA syntheses required for DNA repair, recombination and replication depends on the ability of DNA polymerases to recognize the template and correctly insert the complementary nucleotide. A DNA polymerase is presented with a pool of four structurally similar dNTPs from which it must select the sole correct (i.e., Watson-Crick base paired) substrate for incorporation into the growing DNA strand.

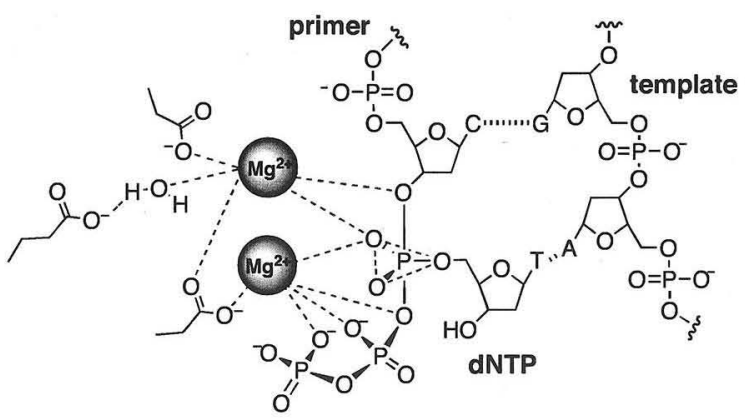

Figure 1 Proposed transition state for DNA polymerase-catalyzed nucleotide insertion. ${ }^{2}$

The mechanisms how these remarkable enzymes achieve this tremendous task are a matter of current interest and intensive discussion since the discovery of the first DNA polymerase, E. coli DNA polymerase I, by Arthur Kornberg about half a century ago. ${ }^{1}$ Enormous efforts from scientists in many disciplines have been undertaken with the aim to gain insights into the complex mechanisms and functions of these molecular machines. ${ }^{3}$ Endeavors along this line are complicated through the fact that higher organisms process more than one DNA polymerase. Currently more than a dozen human DNA polymerases are known that differ significantly in several features. ${ }^{4}$ DNA polymerases that are believed to be involved in DNA replication processes show low error rates (as low as only one error within 1.000 .000 synthesized nucleotide linkages) while certain enzymes that are competent to bypass DNA lesions (caused by e.g. sun light) exhibit high error rates 
of up to one error within one to ten synthesized nucleotide linkages. These properties instantly lead to the questions: What are the mechanistic properties that enable a DNA polymerase to catalyze nucleotide incorporation with a selectivity far greater than that dictated by the thermodynamic differences between base pairs in free solution? Furthermore, what are the origins of the variations in DNA polymerase selectivity?

Recently, a wealth of valuable new insights into DNA polymerase mechanisms were gained through application of carefully designed synthetic nucleotides and oligonucleotides in functional enzyme studies. The applied analogues exhibit features that differ in certain aspects from their natural counterparts and thus, allow the investigation of the involvement and efficacy of the chosen particular aspect (e.g. hydrogen bonding) on the entire complex enzyme mechanism.

\section{Functional DNA Polymerase Studies}

Before starting to summarize the main strategies and designs to investigate DNA polymerases through employment of tailored nucleotide analogues, general aspects for in vitro-investigation of these complex enzymes will be discussed. Structural as well as mechanistic investigations suggest that DNA polymerases make complex interactions with the primer-template and nucleotide substrates during catalysis of DNA polymerization. ${ }^{5}$ Enzyme contacts with the substrates are manifold and reaching up from the catalytic center to several nucleotide pairs within the primer-template stem. In order to investigate the participation of all plausible enzyme-substrate interaction sites, nucleotide probes either have to be converted into the corresponding nucleoside- $5^{\prime}-O$-triphosphates or into building blocks suited for the synthesis of site-specifically modified oligonucleotides. The modified molecules will in turn serve as substrate for functional DNA polymerase studies.

\section{Biographical Sketches}

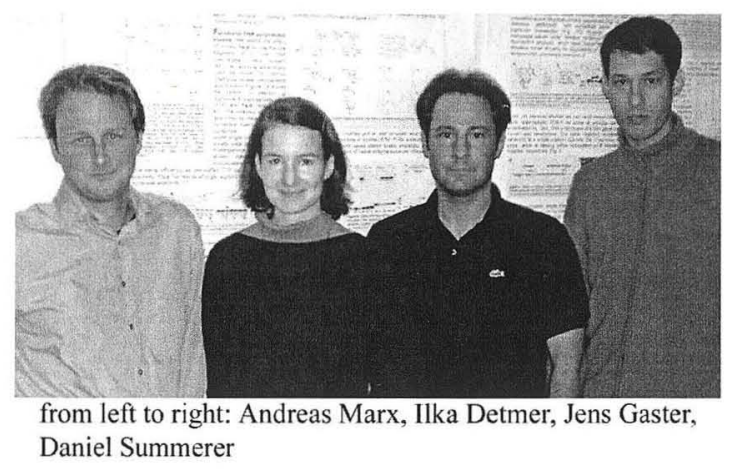

Andreas Marx studied Chemistry in Freiburg (Germany), Sussex (UK), and Bochum (Germany). In 1997 he earned his doctorate at Basel University (Switzerland) with Prof. Bernd Giese. From 1997-1999 he was a EU/JSPS postdoctoral fellow with

Ilka Detmer studied Chemistry in Karlsruhe (Germany) and Bonn (Germany), where she earned her diploma while working in the group of

Jens Gaster studied chemistry at Bonn University (Germany). He is currently working as $\mathrm{PhD}$ student un-

Daniel Summerer studied chemistry at the University of Bonn (Germany) and completed his Diploma with Andreas Marx on the synthesis of modi-
Prof. Hisashi Yamamoto at Nagoya University (Japan). He began his independent career at the Kekulé-Institut für Organische Chemie und Biochemie at Bonn University (Germany) in fall 1999 and is currently heading an independent Junior Re-

Andreas Marx. Currently she is pursuing her $\mathrm{PhD}$ thesis. Her research interests are in the field of synthetic nucleotides for DNA polymerase

der the supervision of Andreas Marx. His research interest include the syn-

fied nucleosides and oligonucleotides. He is currently working on his doctorate on the development of assay formats for high-throughput search Group awarded by the Volkswagen Foundation. His research focus lies in the chemical biology of DNA replication processes. In 2003 he completed his Habilitation and earned the Venia Legendi for Organic Chemistry and Biochemistry.

studies as well as the directed evolution of new enzyme functions.

thesis of modified oligonucleotides as probes for genome analysis.

screening of polymerase variants and is actively involved in combinatorial protein design. 
Most widely applied in DNA polymerase investigations is the so-called primer extension reaction. ${ }^{6}$ The set-up for a primer extension reaction comprises a DNA primer strand equipped with a marker (most widely used is a phosphate group labeled with the radioactive isotope ${ }^{32} \mathrm{P}$ that can easily be attached with an enzyme; fluorescent markers are coming in use recently ${ }^{7}$ ) and annealed to a complementary site on a DNA template strand in such a way that there is a overhang at the $3^{\prime}$-end of the primer to enable template directed DNA synthesis. In the reaction mixture the primer-template is incubated with the DNA polymerase and dNTPs in a suitable reaction buffer. After quenching the reaction products can be separated and analyzed by denaturating polyacrylamide gel electrophoresis and visualized depending on the marker used. From this analysis conclusions can be drawn from the action of a nucleotide analogue on the DNA polymerase function.

A further advantage of gel based investigations is its ease to study DNA polymerase catalyzed reactions quantitatively employing relative simple means. ${ }^{6}$

\section{Modified Substrates for Investigation of DNA Polymerase Function}

In the search for new antiviral therapies numerous nucleotide analogues bearing modified 2 -deoxyribose moieties and/or nucleobases were tested on their action on DNA polymerases in order to understand their mode of action and malfunction as drug. ${ }^{8,9}$ The same holds true for hunts towards the discovery of novel or improved biotechnological applications like highly functionalized DNA for in vitro selection, ${ }^{10,11}$ DNA sequencing applications, ${ }^{12}$ or enzymatic incorporation of probes for e.g. fluorescent detection, affinity modification or chromatid labeling. ${ }^{11,12}$ This review will only cover recent investigations on DNA polymerases that are conducted with the aim to gain insight into the mechanisms of these enzymes. Nevertheless, all these endeavors share the fact that DNA polymerases are the working horses employed and their proficiency in the context of the respective nucleoside analogues is crucial for a successful outcome. Both aspects are certainly interdigitated and borders drawn in this article are thus somehow arbitrary by nature.

\subsection{Nucleobase Modifications}

\subsubsection{Rearrangement of Nucleobase Hydrogen Bond- ing Patterns}

It was first assumed that complementary hydrogen bonding between the nucleobases according to Watson-Crick is the main driving force for the selectivity of DNA polymerases. As pointed out by Benner et al., there are several alternative possible arrangements of mutually exclusive donor and acceptor functionalities in nucleobase pairs. ${ }^{13}$ Only four of these are used by nature and thus, if a model based on complementary inter-nucleobase hydrogen bonding for DNA polymerase selectivity holds true, it should be possible to extend the genetic alphabet through rearrangement of the donor-acceptor patterns. Along this line the Benner laboratory has synthesized numerous nucleoside analogues with scrambled hydrogen bonding patterns. ${ }^{13}$ Perhaps the most successful and widely applied is the iso-G:iso-C pair (Figure 2).

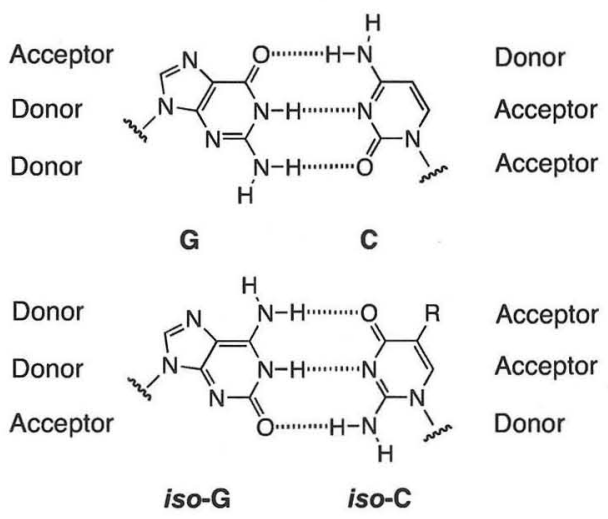

Figure 2 Design of new base pairing modes through scrambling of hydrogen bonding patterns.

Meanwhile, several syntheses of 2'-deoxyisoguanosine (iso-G) have been reported. Seela et al. commenced the synthesis starting with $2^{\prime}$-deoxyguanosine (1). ${ }^{14}$ The unprotected nucleoside was converted into 2-amino- $2^{\prime}$ deoxyadenosine (2), which was subsequently selectively deaminated by diazotization of the 2-amino group affording 2'-deoxyisoguanosine (iso-dG). In order to incorporate iso-dG into oligonucleotides it was converted into amidine 4 which was converted into the $5^{\prime}$ - $O$-dimethoxytrityl (DMT) protected phosphoramidite $\mathbf{5}$ employing standard procedures (Scheme 1).

Switzer et al. reported an alternative procedure for the synthesis of iso-dG containing oligonucleotides by the phosphoramidite strategy (Scheme 2). ${ }^{15}$ Their synthesis started with $2^{\prime}$-deoxyadenosine that was protected at the $3^{\prime}-$ and $5^{\prime}-\mathrm{OH}$ as bis(tert-butyldimethylsilyl)ethers to yield 6 . After oxidation of $\mathbf{6}$ with $m$-chloroperoxybenzoic acid (MCPBA) to form the N1-oxide 7 irradiation with $252 \mathrm{~nm}$ light lead to the protected $2^{\prime}$-deoxyisoguanosine derivative 8. Protection group manipulation yielded a protected phosphoramidite building block $\mathbf{1 0}$ suitable for solid-phase oligonucleotide synthesis. Noteworthy as pointed out by several researchers, protection of the 2-oxygene was crucial for the successful synthesis of oligonucleotides containing iso-dG moieties.

For the synthesis of the corresponding $5^{\prime}$ - $O$-triphosphate 2 -deoxyisoguanosine derivative Benner et al. started with compound $11 .{ }^{16} 11$ was 3 -O-acetylated and subsequently the $5^{\prime}-O$-DMT ether was cleaved with acid to yield 12 . In a one-pot reaction procedure originally reported by Ludwig and Eckstein ${ }^{17} 12$ was converted into desired 5'-Otriphosphate 2 -deoxyisoguanosine (13) after cleavage of the protecting groups by treatment with aqueous ammonia (Scheme 3). 
<smiles>[2H]C(C)(C)[N+]([PH])(CC)OCCC#N</smiles>

Scheme 1 a) HMDS; b) $\mathrm{NH}_{3},\left(\mathrm{Me}_{3}\right)_{3} \mathrm{SiOSO}_{2} \mathrm{CF}_{3}$, toluene; c) $\mathrm{Me}$ $\mathrm{OH}, \mathrm{H}_{2} \mathrm{O}$; three steps: $71 \%$; d) $\mathrm{NaNO}_{2}, \mathrm{H}_{2} \mathrm{O}, \mathrm{AcOH}, 59 \%$; e) $\mathrm{Me}_{2} \mathrm{NC}(\mathrm{OMe})_{2} \mathrm{Me}, \mathrm{MeOH}, 90 \%$; f) dpc-Cl, DIEA, pyridine, $81 \%$; g) DMTCl, pyridine, $65 \%$; h) $\left(\mathrm{NCCH}_{2} \mathrm{CH}_{2} \mathrm{O}\right) \mathrm{PN}(i-\mathrm{Pr})_{2}(\mathrm{Cl})$, DIEA, $\mathrm{CH}_{2} \mathrm{Cl}_{2}, 94 \%$. dpc $=$ diphenylcarbamoyl.

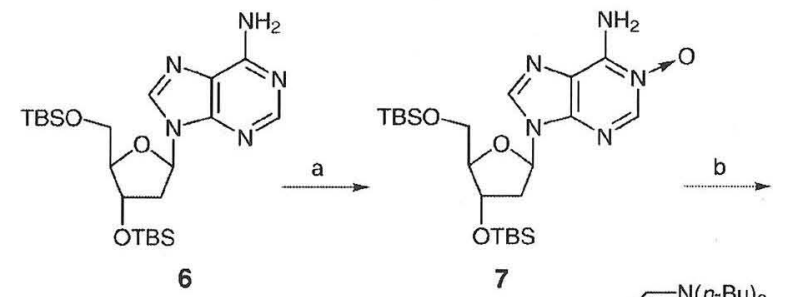<smiles>CCCCNC(C)=O</smiles><smiles></smiles>

Scheme 2 a) MCPBA, $\mathrm{CH}_{2} \mathrm{Cl}_{2}, 80 \%$; b) hv, EtOH, $\mathrm{H}_{2} \mathrm{O}, 42 \%$; c) $n$ $\mathrm{Bu}_{2} \mathrm{NC}(\mathrm{OMe})_{2}$, pyridine, $71 \%$; d) dpc-Cl, DIEA, pyridine, $92 \%$; e) TBAF, THF, 89\%; f) DMTCl, pyridine, $78 \%$; g) $\left(\mathrm{NCCH}_{2} \mathrm{CH}_{2} \mathrm{O}\right) \mathrm{PN}(i-\mathrm{Pr})_{2}(\mathrm{Cl})$, DIEA, $\mathrm{CH}_{2} \mathrm{Cl}_{2}, 80 \%$.

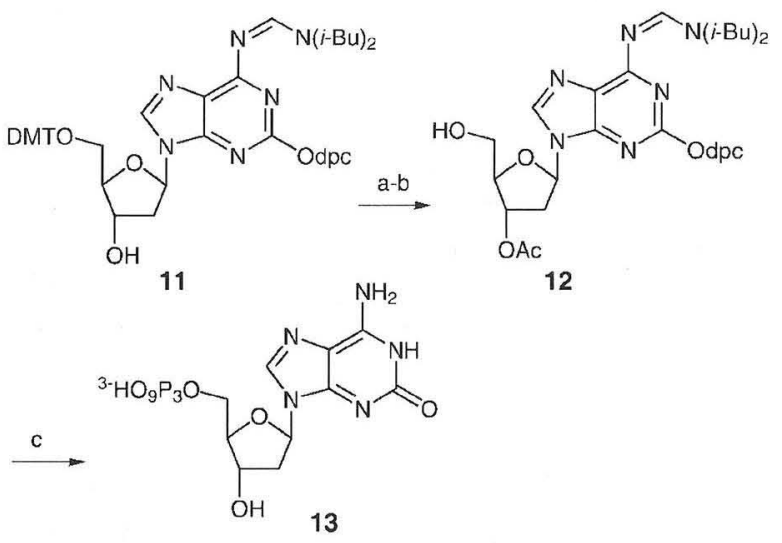

Scheme 3 a) $\mathrm{Ac}_{2} \mathrm{O}, \mathrm{DMAP}, \mathrm{Et}_{3} \mathrm{~N}$, pyridine; b) $\mathrm{HCl}, \mathrm{MeOH}, \mathrm{CHCl}_{3}$, two steps: $45 \%$; c) 2-chloro-4H-1,3,2-benzodioxaphosphorin-4-one, tributylammonium pyrophosphate, $\mathrm{Bu}_{3} \mathrm{~N}, \mathrm{I}_{2}, \mathrm{NH}_{3}, 17 \%$.

The synthesis of iso-dC derivatives turned out to be more cumbersome. ${ }^{18}$ During the synthesis of $i$ so- $\mathrm{dC}$ derivatives it was found that the N2-benzoyl-2'-deoxy-iso-C does not tolerate deprotection with ammonium hydroxide, giving significant hydrolytic deamination to dU (about 15\%) along with iso-dC after treatment for 17 hours. Use of dimethylformamidine for protection of $\mathrm{N} 2$ was attempted to limit the time of exposure to only 1 hour. However, it was discovered that this protecting group activated the iso-dC toward depyrimidination. 2'-Deoxy-5-methylisocytidine ( $5 \mathrm{me}$-iso-dC) was found to be a possible solution to both problems. ${ }^{19}$ The synthesis for a $5 \mathrm{me}$-iso- $\mathrm{dC}$ building block suitable for oligonucleotide synthesis started with thymidine that was converted into $2,5^{\prime}$-anhydrothymidine (14) by treatment with diethyl azodicarboxylate (DEAD) and triphenylphosphine. ${ }^{19}$<smiles>Cc1cn(C23CC(O)C(CC2O)O3)c(N)nc1=O</smiles><smiles>[R]CN(CC)P(CC)OCCC#N</smiles>

Scheme 4 a) $\mathrm{NH}_{3}, \mathrm{MeOH}, 72 \%$; b) $\mathrm{BzCl}$, pyridine, than $\mathrm{NaOH}$, Me$\mathrm{OH}, \mathrm{H}_{2} \mathrm{O}$, pyridine, $63 \%$; c) DMTCl, pyridine, $\mathrm{Et}_{3} \mathrm{~N}$, DMAP, $61 \%$; d) $\left(\mathrm{NCCH}_{2} \mathrm{CH}_{2} \mathrm{O}\right) \mathrm{PN}(i-\mathrm{Pr})_{2}(\mathrm{Cl})$, DIEA, $\mathrm{CH}_{2} \mathrm{Cl}_{2}, 73 \%$. 
Treatment of 2,5'-anhydrothymidine (14) with saturated methanolic ammonia afforded $\mathbf{5 m e - i s o - d C ~ i n ~} 72 \%$ yield (Scheme 4). To afford $\mathbf{1 5}$ selective benzoylation of the aromatic amino group was achieved by first peracylation and subsequent cleavage of the benzoate esters. 15 was converted into the phosphoramidite building block 16 by standard 5'-O-dimethoxytritylation and 3'-O-phosphitilation. 16 was incorporated into oligonucleotides using standard automated solid-phase synthesis 2-cyanoethyl phosphoramidite chemistry.

In order to synthesize the corresponding $5^{\prime}-O$-triphos-

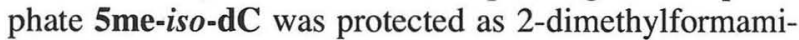
dine 17 by treatment with dimethylformamide dimethyl acetal (Scheme 5). Formamidine protection was chosen over $\mathrm{N}$-benzoyl protection due the fact that it is more stable to acid conditions and the DMT ether can be easier cleaved without concomitant depyrimidination. 5'Dimethoxytritylation, 3'-acetylation and subsequent 5'DMT ether cleavage afforded $\mathbf{1 8}$, which was converted into the protected $5^{\prime}-O$-triphosphate 19 by the Ludwig and Eckstein procedure followed by cleavage of the protecting groups with aqueous ammonia. ${ }^{16}$
5me-iso-dC<smiles>CN=Cc1nc(=O)c(C)cn1C1CC(O)C2COCC21</smiles>

18<smiles>Cc1cn(C2CC(O)C3OCC32)c(N)nc1=O</smiles><smiles>CN=Cc1nc(=O)c(C)cn1C1CC(O)C(CO)O1</smiles>

17<smiles>Cc1cn(C2CC(O)C(COP(=O)(O)O)O2)c(N)nc1=O</smiles>

19

\subsubsection{Deleting Nucleobase Hydrogen Bonding Accep-} tors and/or Donors

In order to investigate the impact of single hydrogen bonds in their participation on right DNA polymerase function several analogues bearing nucleobase surrogates with deleted hydrogen bond donors or acceptors were developed and tested on their action on DNA polymerases.

Early work along this line was reported by Strazewski and Tamm. ${ }^{20}$ They described the development of nucleobase surrogates 25-27 (Figure 3). As the authors summarized the synthesis of the nucleoside derivatives is best performed as depicted in Scheme $6 .{ }^{20}$ Glycosylation was performed by use of 1-O-acetyl-2,3,5-O-tribenzoyl- $\beta$-Dribofuranose (20) and the persilylated nucleobase 21 under Lewis acid catalysis. N-Acetylation, subsequent cleavage of the benzoyl esters and selective silylation of the $3^{\prime}$ and $5^{\prime}$ positions using 1,3-dichloro-1,1,3,3-tetraisopropylsiloxane afforded 23. 2'-Deoxygenation to yield 24 was performed through conversion into the thiocarbonate and subsequent reduction with tributyl tinhydride.

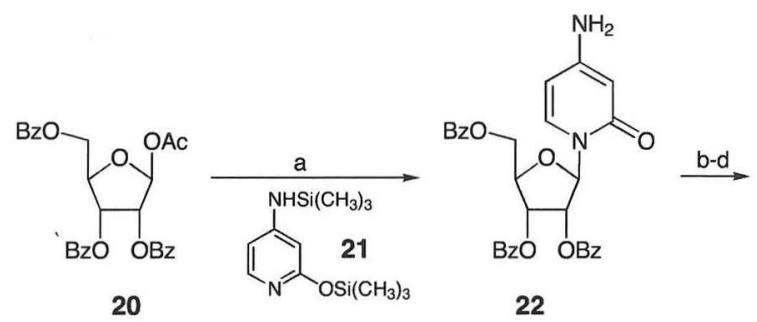

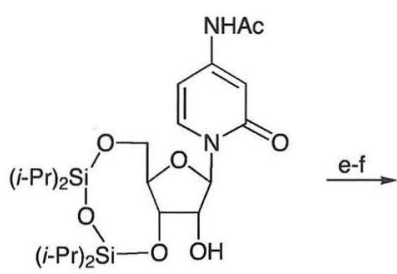

23

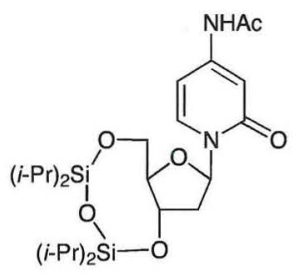

24
Scheme 5 a) $\mathrm{Me}_{2} \mathrm{NCH}(\mathrm{OMe})_{2}, \mathrm{DMF}, 97 \%$; b) DMTCl, DMAP, pyridine, $75 \%$; c) $\mathrm{Ac}_{2} \mathrm{O}$, DMAP, $\mathrm{Et}_{3} \mathrm{~N}$, pyridine, $89 \%$; d) $\mathrm{HCl}, \mathrm{MeOH}$, $64 \%$; e) 2-chloro- $4 H-1,3,2$-benzodioxaphosphorin-4-one, tributylammonium pyrophosphate, $\mathrm{Bu}_{3} \mathrm{~N}, \mathrm{I}_{2}, \mathrm{NH}_{3}, 42 \%$.

First, Benner and coworker tested the Klenow fragment of $E$. coli DNA polymerase I and found that this enzyme is proficient in processing iso-dG and iso-dC in a templatedirected manner. ${ }^{14,16}$ Nevertheless, the analogues were incorporated with a reduced fidelity compared to the natural substrates. This feature is observed with other nucleotides and DNA polymerases containing non-standard hydrogen bonding arrangements as well. The reduced fidelity is attributed to the presence of different minor tautomers that code for misincorporation of undesired nucleotides.
Scheme 6 a) $\mathrm{SnCl}_{4}, \mathrm{CH}_{2} \mathrm{Cl}_{2}$; b) $\mathrm{Ac}_{2} \mathrm{O}$; c) $\mathrm{NaOMe}$; d) 1,3-dichloro1,1,3,3-tetraisopropylsiloxane; e) $p$-TolOC $(S) \mathrm{Cl}, \mathrm{DMAP}, \mathrm{MeCN}$; f) $\mathrm{Bu}_{3} \mathrm{SnH}$.

Compound 24 was converted into the corresponding $5^{\prime}-O$ triphosphate and incorporated into oligonucleotides. Following more or less this strategy the nucleotide analogues 25-27 were synthesized (see Figure 3).<smiles>CCn1ccccc1=O</smiles>

25<smiles>CCn1cccnc1=O</smiles>

26<smiles>CC(C)n1ccc(N)cc1=O</smiles>

27
Figure 3 
During experiments designed to determine the response of the Klenow fragment of $\boldsymbol{E}$. coli DNA polymerase I to nucleotide analogues $\mathbf{2 5 - 2 7}$ in the template strand it was found that 25 leads to non-specific incorporation while compound 26 causes a block of replication. ${ }^{21}$ The results obtained with compound 27 were most surprising as it codes for $\mathrm{dC}$ and to a lesser extend $\mathrm{dT}$ incorporation. The authors speculate that this property might be originated from the greater basicity of the 2-carbonyl group of $\mathbf{2 7}$ (compared to $\mathrm{dC}$ ) that stabilizes the imino-enol form of the compound which than can base pair with $\mathrm{dC}$.

In a recent strategy Yokoyama et al. combined features of hydrogen bonding groups with steric effects. ${ }^{22}$ In order to generate a new base analogue with novel base-pairing properties 4-methylpyridin-2-one, as in $\mathbf{3 1}$ and $\mathbf{3 2}$ as nucleobase surrogate, was designed in which the 4-amino group of 27 was substituted with a methyl group (Scheme 7). Yokoyama et al. speculated that in contrast to 27, the hydrophobicity of $\mathbf{3 1}$ and $\mathbf{3 2}$ may prevent base pairing with the natural pyrimidines, $\mathrm{dC}$ and $\mathrm{dT}$ and sterically clash with the 6-amino group of $\mathrm{dA}$ and thus, may eliminate base pairing with A. Thus, the nucleotide derivatives $\mathbf{3 1}$ and $\mathbf{3 2}$ should pair specifically to dG moieties. The probes were synthesized starting from $\mathbf{2 8}$ which was silylated and subsequently glycosylated by use of $\mathbf{2 0}$ and Lewis acid catalysis to form the anticipated nucleoside 29 after saponification. ${ }^{22}$ The nucleoside was converted into the corresponding $2^{\prime}$-deoxyribose derivative $\mathbf{3 0}$ as described in Scheme 7. Standard 5'-OH protection as DMT ether and conversion into the cyanoethyl-protected phos-<smiles>Cc1ccnc(O)c1</smiles>

28<smiles>[R10]OCC1OC(n2ccc(C)cc2=O)CC1OP(NC(C)C)OCCC#N</smiles>

31

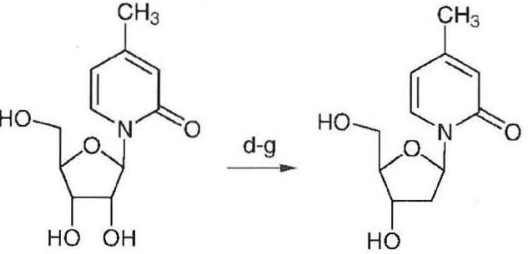

29

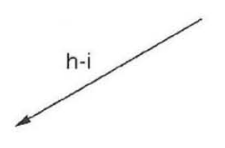

30

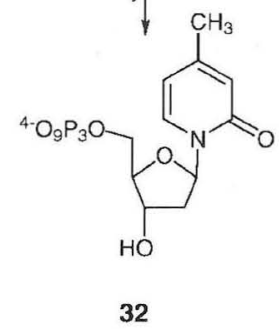

Scheme 7 a) HmDS; b) 20, $\mathrm{SnCl}_{4}, 1,2$-dichloroethane; c) $\mathrm{NH}_{3}$, $\mathrm{MeOH}$; d) 1,3-dichloro-1,1,3,3-tetraisopropyldisiloxane pyridine, DMF; e) thiocarbonyldiimidazolide, DMF; f) $\mathrm{AIBN}, \mathrm{Bu}_{3} \mathrm{SnH}$, toluene, reflux; g) TBAF, THF; h) DMTCl, pyridine; i) $\left(\mathrm{NCCH}_{2} \mathrm{CH}_{2} \mathrm{O}\right) \mathrm{PN}(i-\mathrm{Pr})_{2}(\mathrm{Cl})$, DIEA,THF; j) $\mathrm{POCl}_{3}$, trimethyl phosphate, followed by bis(tri- $n$-butylammonium) pyrophosphate, DMF, $\mathrm{Bu}_{3} \mathrm{~N}$. phoramidite 31 yielded a building block suitable for standard automated solid-phase synthesis. The corresponding $5^{\prime}-O$-triphosphate $\mathbf{3 2}$ was synthesized by treatment of $\mathbf{3 0}$ with phosphorus oxytrichloride in trimethyl phosphate followed by addition of bis(tri- $n$-butylammonium) pyrophosphate and tributylamine.

Yokoyama et al. investigated the Klenow fragment of $E$. coli DNA polymerase I in its interplay with the artificial substrates 4-methylpyridin-2-one, derived from $\mathbf{3 1}$ in oligonucleotides and 32. They observed dual specificity of base pairing: 4-methylpyridin-2-one serves as a $\mathrm{dC}$-analogue in the template strand while the triphosphate 32 behaves as a dT-analogue rather than a $\mathrm{dC}$-analogue. The authors speculate that the observed dual specificity origins from differential orientation of the protons in the 4methyl group when present in the triphosphate or in the template. In the template the rotation of the 4-methyl group is restricted by the stacking with neighboring bases, while in the triphosphate case the methyl group easily rotates. Nevertheless, further structural investigations are required to corroborate this model.

It has been pointed out by several researchers that specific recognition and positioning of the $\mathrm{O} 2$ atoms of pyrimidines (see Figure 4) and N3 atoms of purines by protein side chains of DNA polymerases may be important to the mechanism by which these enzymes enhance selectivity of the DNA replication process. ${ }^{3 \mathrm{a}, \mathrm{c}, \mathrm{d}}$<smiles>Cc1cn(C)c(=O)[nH]c1=O</smiles>

$\mathrm{T}$<smiles>Cc1c[nH]c(=O)c(C)c1</smiles>

33<smiles>Cn1ccc(N)nc1=O</smiles>

C<smiles>Cc1ccc(N)nc1</smiles>

34
Figure 4

In order to test the significance of these interactions, several nucleobase analogues with deleted minor groove binding functionalities were synthesized and employed in functional enzyme studies. These analogues were designed to potentially maintain the Watson-Crick binding mode.

In the synthesis of $\mathbf{3 3}$ and $\mathbf{3 4}$, developed by Hsieh and McLaughlin, 2-(benzyloxy)-3-methyl-5-iodopyridine (36) was reacted with protected glycal 35 in which a Heck-type coupling is employed to form the $\mathrm{C}-\mathrm{C}$ bond between both reactants (Scheme 8 ). ${ }^{23}$ This type of C-nucleoside forming reaction was based on earlier reports from Daves et al. ${ }^{23 b}$ Remarkably, the C-nucleoside 37 was formed in high yield (approximately $90 \%$ ) as $\beta$-isomer as sole $\mathrm{Cl}^{\prime}$-epimer. After deprotection of the silyl enol ether and reduction of the resulting ketone, the 2'-deoxyribose sugar was generated to yield $\mathbf{3 8}$ which was converted into the corresponding $5^{\prime}-O$-triphosphate $39 .^{24}$ 


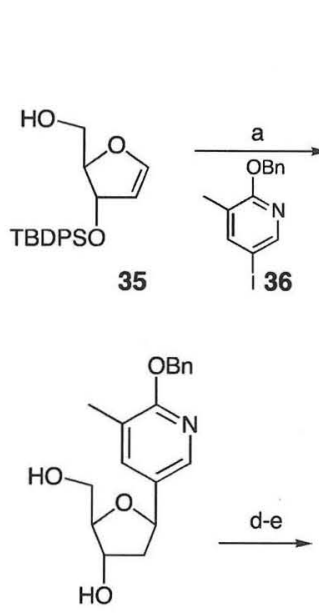

38

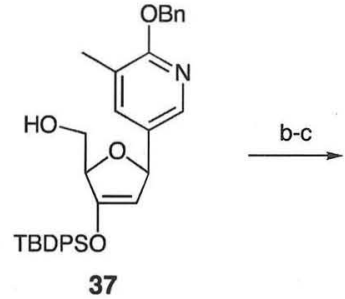<smiles></smiles>

39
Scheme 8 a) $\mathrm{Pd}(\mathrm{dba})_{2}, \mathrm{Ph}_{2} \mathrm{P}\left(\mathrm{CH}_{2}\right)_{3} \mathrm{PPh}_{2}, \mathrm{Bu}_{3} \mathrm{~N}, \mathrm{MeCN}, 90 \%$; b) TBAF, THF, 82\%; c) $\mathrm{NaBH}(\mathrm{OAc})_{3}, \mathrm{MeCN}, 99 \%$; d) $\mathrm{POCl}_{3}$, $\mathrm{MeO}_{3} \mathrm{PO}, 1,8$-bis(dimethylamino)naphthalene, followed by bis(tri- $n$ butylammonium) pyrophosphate, DMF, $\mathrm{Bu}_{3} \mathrm{~N}$; e) $\mathrm{Pd} / \mathrm{C}, \mathrm{H}_{2}, \mathrm{H}_{2} \mathrm{O}$, $\mathrm{EtOH}$.

In a similar fashion, the respective $\mathrm{C}$-nucleoside analogue 41 of $\mathrm{dC}$ was prepared from 2-aminopyridine which was iodinated and N2-benzoyl protected prior to coupling with the glycal 35 (Scheme 9). ${ }^{23}$ In this case the coupling yield was somehow diminished and $\mathrm{C}-\mathrm{C}$ bond formation worked best when $\mathrm{P}\left(\mathrm{C}_{6} \mathrm{~F}_{5}\right)_{3}$ was employed as ancillary ligand.<smiles>Cc1ccc(N(C)C(C)C)nc1</smiles><smiles></smiles>

Scheme 9 a) $\mathrm{Pd}(\mathrm{dba})_{2}, \mathrm{P}\left(\mathrm{C}_{6} \mathrm{~F}_{5}\right)_{3}, \mathrm{Bu}_{3} \mathrm{~N}, \mathrm{MeCN}, 36 \%$; b) TBAF, THF, 78\%; c) $\mathrm{NaBH}(\mathrm{OAc})_{3}, \mathrm{MeCN}, 87 \%$; d) $40 \% \mathrm{MeNH}_{2}, 60 \%$; e) $\mathrm{Me}_{2} \mathrm{NCH}\left(\mathrm{OCH}_{3}\right)_{2}$, $\mathrm{MeOH}$; f) $\mathrm{POCl}_{3}, \mathrm{MeO}_{3} \mathrm{PO}, 1,8$-bis(dimethylamino)naphthalene, followed by bis(tri- $n$-butylammonium) pyrophosphate, $\mathrm{DMF}, \mathrm{Bu}_{3} \mathrm{~N} ; \mathrm{g}$ ) concd $\mathrm{NH}_{4} \mathrm{OH}$.

An alternative synthesis for $\mathbf{4 1}$ derivatives was developed by Hildbrand and Leumann (Scheme 10). ${ }^{25}$ Their synthesis is based on the reports by Krohn et al. and Kraus et al. for the synthesis of C-nucleosides. ${ }^{26}$ Starting with 45 , bro- mine was exchanged with lithium, subsequent reaction with lactone 44 and reduction of the resulting $\mathrm{OH}$ group with $\mathrm{Et}_{3} \mathrm{SiH} / \mathrm{BF}_{3} \cdot \mathrm{Et}_{2} \mathrm{O}$ yielded the desired $\beta$-C-nucleoside 46 as sole isomer. The respective $2^{\prime}$-deoxynucleoside $\mathbf{4 1}$ was synthesized starting from 46 in six steps (N2benzoylation, debenzylation with $\mathrm{BBr}_{3}$, selective protection of the $3^{\prime}$ - and 5'-hydroxyl groups, deoxygenation of the $2^{\prime}-\mathrm{OH}$ group, desilylation, and debenzoylation).

Both dT and dC analogues $\mathbf{3 8}$ and $\mathbf{4 1}$ were converted into the corresponding 5'-O-triphosphates 39 and 43, respectively (Schemes 8 and 9). 38 was phosporylated employing a standard procedure. The O4-benzyl protecting group was hydrogenolytically cleaved to liberate the unprotected nucleoside triphosphate 39. During the synthesis of the corresponding triphosphate $\mathbf{4 3}$ it was found that cleavage of the N4-benzoyl group is incompatible with the triphosphate moiety. Thus, $\mathbf{4 1}$ was transferred to the corresponding N4-dimethyl formamidine 42. Using a standard protocol 42 was converted into the protected triphosphate. Deprotection to yield $\mathbf{4 3}$ was achieved by treatment with ammonia. $^{24}$

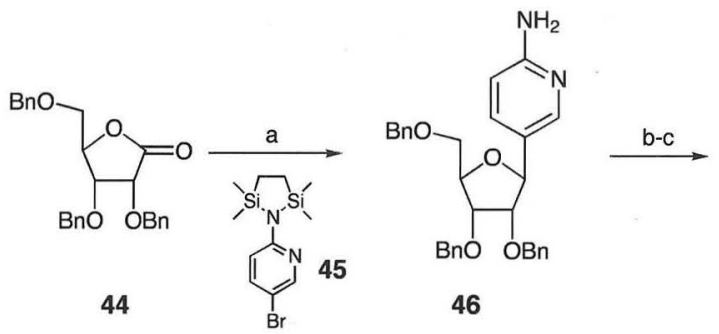

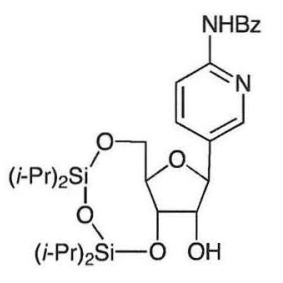

47

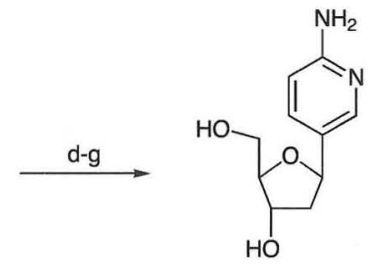

41
Scheme 10 a) 45 , BuLi, THF, then $\mathrm{Et}_{3} \mathrm{SiH}, \mathrm{BF}_{3} \cdot \mathrm{Et}_{2} \mathrm{O}, \mathrm{CH}_{2} \mathrm{Cl}_{2}, 64 \%$; b) $\mathrm{BzCl}$, pyridine, $\mathrm{CH}_{2} \mathrm{Cl}_{2}$, then $\mathrm{BBr}_{3}, \mathrm{CH}_{2} \mathrm{Cl}_{2}, 70 \%$; c) 1,3-dichloro1,1,3,3-tetraisopropylsiloxane, pyridine, $75 \%$; d) $p$-TolOC $(S) \mathrm{Cl}$, DMAP, MeCN, $81 \%$; e) AIBN, $\mathrm{Bu}_{3} \mathrm{SnH}$, toluene, $84 \%$; f) TBAF, THF, $86 \%$; g) $40 \% \mathrm{NH}_{4} \mathrm{OH}, 83 \%$.

Both, 39 and 43 were employed in functional DNA polymerase studies. It was found that both pyrimidine nucleotides lacking the 2-keto group are not accepted as substrates for the Klenow fragment of $E$. coli DNA polymerase $\mathrm{I}^{24}$ This study indicates that contacts with the 2keto groups of incoming pyrimidine nucleotides are indeed essential for processing nucleotide substrates by at least the DNA polymerases studied.

Nevertheless, McLaughlin et al. could show recently, that a nucleoside triphosphate bearing a 2-aminopyridine residue (34) is readily incorporated by a DNA polymerase namely HIV-1 reverse transcriptase. ${ }^{27}$ In a similar fashion 
as depicted in Scheme 9 the authors synthesized the 2',3'dideoxy derivative $\mathbf{5 0}$ (Scheme 11). Changing the catalyst for the Heck-type reaction allowed coupling of the unprotected pyridine derivative to glycal 35 to form 48 in high yield. Desilylation, hydrazone formation, and reduction yielded the $2^{\prime}, 3^{\prime}$-dideoxy derivative 49 , which was converted into the corresponding triphosphate $\mathbf{5 0}$ as depicted above.

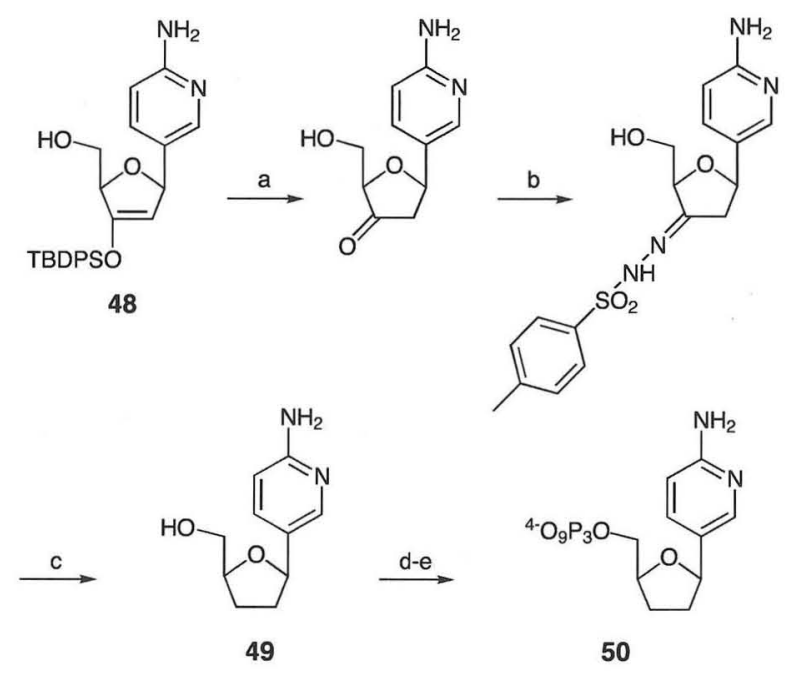

Scheme 11 a) TBAF, $\mathrm{CH}_{3} \mathrm{COOH}$, THF, 97\%; b) p-toluylsulfonylhydrazide, $\mathrm{MeOH}, 97 \%$; c) $\mathrm{Na}(\mathrm{OAc})_{3} \mathrm{BH}, \mathrm{CH}_{3} \mathrm{COOH}, \mathrm{MeCN}, 86 \%$; d) $\mathrm{Me}_{2} \mathrm{NCH}\left(\mathrm{OCH}_{3}\right)_{2}, \mathrm{MeOH}, 94 \%$; e) $\mathrm{POCl}_{3}, \mathrm{MeO}_{3} \mathrm{PO}, 1,8$-bis(dimethylamino)naphthalene, followed by bis(tri- $n$-butylammonium) pyrophosphate, DMF, $\mathrm{Bu}_{3} \mathrm{~N}$, followed by $\mathrm{NH}_{4} \mathrm{OH}, 7 \%$ from 49 .

In contrast to the results obtained with the Klenow fragment, incorporation of the modified nucleotide $\mathbf{5 0}$ with deleted 2-carbonyl function was observed with HIV-1 reverse transcriptase and to a lesser extent with human DNA polymerase $\gamma$ while $\mathbf{5 0}$ was not processed by human polymerases $\alpha$ and $\beta$. As the authors suggest, these properties might be exploited for the development of new antiviral strategies.

To probe interactions of DNA polymerases with the N3 group in purines Spratt et al. synthesized 3-deaza-2'deoxyguanine derivatives $\mathbf{5 3}$ (Scheme 12). ${ }^{28}$ The synthe-

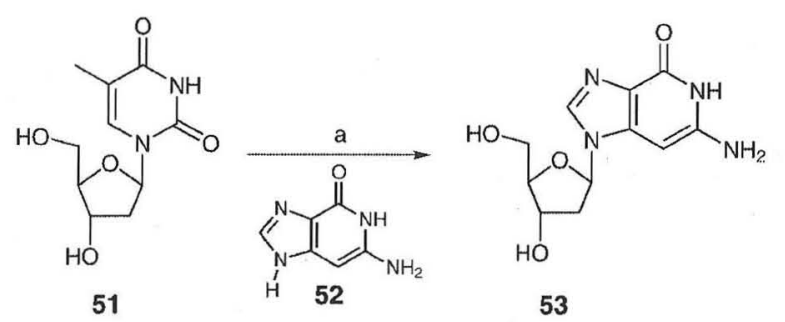

Scheme 12 a) 52, thymidine phosphorylase, purine nucleoside phosphorylase, sodium phosphate $\mathrm{pH}$ 7.0. sis by Spratt and coworkers follows reports by Krenitsky et al. using a two-enzymes system composed of thymidine phosphorylase and purine nucleoside phosphorylase to substitute thymine in thymidine (51) with a purine nucleobase analogue. ${ }^{29}$

Thus, in the presence of 3-deazaguanine (52) thymidine (51) was treated with purine nucleoside phosphorylase and thymidine phosphorylase in a phosphate buffer solution to yield the desired $2^{\prime}$-deoxyguanosine analogue 53. ${ }^{28}$ Employing standard procedures, this analogue was converted into the corresponding triphosphate or incorporated into oligonucleotides. In a first set of experiments Spratt investigated the importance of minor groove binding in the context of the Klenow fragment and could show a functional connection between the Arg668 side chain of the Klenow fragment and the minor groove of the primer strand. ${ }^{30}$ Spratt concludes that the hydrogen bond between N3 in dG-residues and Arg668 orients the side chain to enhance phosphor diester bond formation. Recently, by employment of the triphosphate of 3-deaza-2'-deoxyguanosine (53) insight into the selectivity mechanisms of eucaryotic DNA polymerase $\eta$, an error prone DNA polymerase proficient in bypass synthesis of several DNA lesions, was gained. ${ }^{31}$ The obtained results suggest that DNA polymerase $\eta$ makes only a single functional contact with the DNA minor groove at the position of the incoming dNTP. In this regard this enzyme differs from high-fidelity DNA polymerases and might explain the ability of DNA polymerase $\eta$ to bypass several bulky DNA lesions.

\subsubsection{Non- Nucleobase Surrogates}

As mentioned before, for a long time hydrogen bondings according to the Watson-Crick rule are viewed as 'informational'. Consequently, it is a common perception that these interactions are primarily responsible for the ability of DNA polymerases to drive formation of the canonical nucleobase pairs.

In order to evaluate the participation of hydrogen bonding and shape fitting in DNA replication selectivity mechanisms Kool described a functional strategy based on chemically modified DNA polymerase substrates. ${ }^{3 \mathrm{~d}} \mathrm{He}$ developed nucleotide analogues in which the polar natural DNA nucleobases are replaced by non-polar aromatic molecules (Figure 5). Some of them closely mimic the shape and size of the natural nucleobases but have at least significantly diminished ability to form stable hydrogen bonds. Kool and coworkers synthesized non-polar nucleobase surrogates through coupling of the aromatic moieties to $\alpha$-chlorosugar synthon $\mathbf{5 4}$ involving organocadmium derivatives of the aromatic species (Scheme 13). ${ }^{32}$ The primary products from these transformations are the $\alpha$-configurated isomers 55a. 


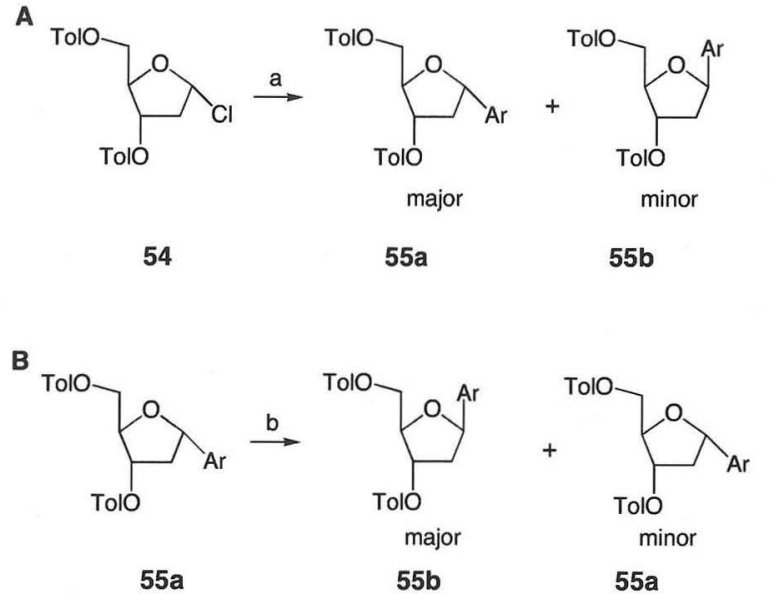

Scheme 13 a) $\mathrm{ArMgBr}, \mathrm{CdCl}_{2}$, THF; b) cat. $\mathrm{PhSO}_{3} \mathrm{H}$, xylene, $\mathrm{H}_{2} \mathrm{O}$.

However, it is possible to equilibrate the protected $\alpha$-Cnucleosides to $\beta$-isomers $\mathbf{5 5} \mathbf{b}$ by treatment with benzenesulfonic acid in refluxing xylene in the presence of small amounts of water. Using this approach Kool et al. synthesized a plethora of C-nucleosides as depicted in Figure 5.<smiles></smiles><smiles>OCC1OC2CC(O)C(O)C12</smiles><smiles></smiles><smiles>OCC1C(O)CC1c1ccc2ccccc2c1</smiles><smiles>Cc1cc(C)c(C2CC(O)C(CO)O2)cc1C</smiles><smiles>Cc1cc(C2CC(O)C(CO)C2)c(F)cc1F</smiles>

Figure 5

For DNA polymerase investigations the resulting C-nucleoside analogues were converted into the respective 5 $O$-triphosphates and phosphoramidite building blocks suitable for the synthesis of modified oligonucleotide substrates (Scheme 14). ${ }^{32}$

In first experiments Kool and coworkers studied the insertion of dNTP opposite dF, the nonpolar isostere of thymidine in the template strand (Figure 6). ${ }^{33}$ If purely hydrogen bonding drives selective nucleotide incorporation one would expect that incorporation opposite $\mathbf{d F}$ is very inefficient and unselective. Interestingly, they observed the contrary when studying the Klenow fragment. This enzyme was able to promote nucleotide insertion opposite $\mathbf{d F}$ efficiently with a remarkable selectivity by preferential incorporation of $\mathrm{dA}$. In the next set of experiments Kool et al. turned the base pair around. ${ }^{34}$

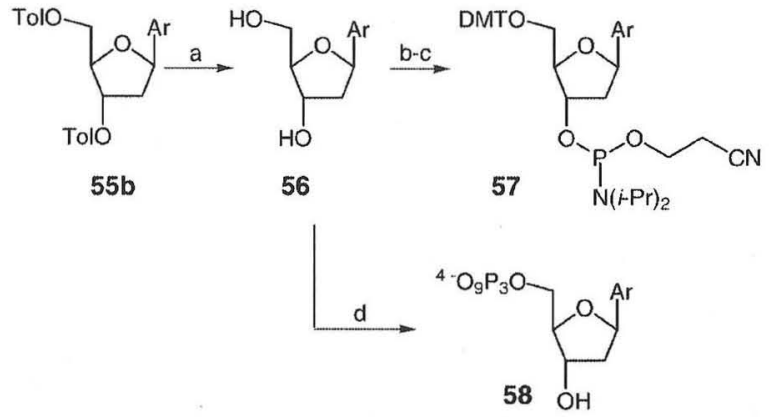

Scheme 14 a) $\mathrm{NaOMe}, \mathrm{MeOH}$; b) DMTCl, DMAP, pyridine, $\mathrm{CH}_{2} \mathrm{Cl}_{2}$; c) $\left(\mathrm{NCCH}_{2} \mathrm{CH}_{2} \mathrm{O}\right) \mathrm{PN}(i-\mathrm{Pr})_{2}(\mathrm{Cl})$, DIEA, $\mathrm{CH}_{2} \mathrm{Cl}_{2} ;$ d) $\mathrm{POCl}_{3}$, $\mathrm{MeO}_{3} \mathrm{PO}, 1,8$-bis(dimethylamino)naphthalene, followed by bis(tri- $n$ butylammonium) pyrophosphate, $\mathrm{DMF}, \mathrm{Bu}_{3} \mathrm{~N}$.

They found that dFTP was inserted by the polymerase still highly efficient, and that the selectivity was nearly as high as for the natural substrate TTP opposite dA. Based on this results Kool proposed that hydrogen bonding in enzymatic DNA synthesis was not as important as commonly believed.

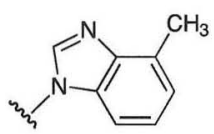

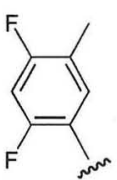

$\mathbf{F}$

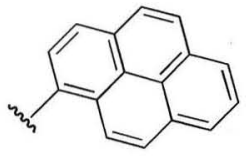

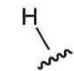

AP
Figure 6

This assumption was further supported by recent findings that a throughout artificial $\mathbf{d F}$-dZ pair (Figure 6) was processed by polymerases efficiently and with considerable selectivity indicating that steric effects play at least a significant role in DNA polymerase selectivity processes. ${ }^{35}$ Further evidence for such a steric model were derived from studying dPTP insertion opposite abasic sites in the template strand..$^{36}$ The pyrene group is nearly as large as natural base pairs and obviously has no significant hydrogen bonding ability. The space occupied by the pyrene moiety fills in the blank of the removed base in the template strand. Remarkably, the Klenow fragment and T7 DNA polymerase were found to insert dPTP opposite abasic sites AP more efficiently than opposite natural bases or another pyrene bearing moiety in the template. Kool et al. concluded from these results that hydrogen bonding is not required to achieve high incorporation efficiencies and that significant levels of selectivity can be achieved without hydrogen bonds.

In order to investigate minor groove contacts of the DNA polymerase with the DNA substrate Kool and Morales synthesized the nucleoside analogue $\mathbf{d Q} \cdot{ }^{37}$ This analogue is isosteric with dA but lacks all Watson-Crick hydrogen bonding groups. In contrast to the earlier employed derivative $\mathbf{d Z}, \mathbf{d Q}$ has a minor groove acceptor nitrogen like dA. 
<smiles>OCCOC1OC2CC1C2O</smiles>

54

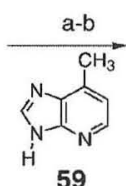

59<smiles>Cc1ccnc2c1ncn2C1CC(O)C(CO)C1</smiles>

dQ
Scheme 15 a) $\mathrm{NaH}, \mathrm{MeCN}, 53 \%$; b) $\mathrm{NaOMe}, \mathrm{MeOH}, 72 \%$.

dQ was synthesized through coupling of the heterocycle 59 with the $\alpha$-chlorosugar synthon $\mathbf{5 4}$ in acetonitrile under promotion of $\mathrm{NaH}$ (Scheme 15). After cleavage of the toluoyl esters with sodium methoxide in methanol pure dQ could be isolated. Standard DMT ether formation and 3'-O-phosphitylation yielded a suitable phosphoramidite building block for the synthesis of modified oligonucletides. The respective $5^{\prime}$ - $O$-triphosphate was synthesized employing a protocol originally described by Kovács and Ötvös. ${ }^{38}$

In functional studies of the Klenow fragment employing the artificial analogues $\mathbf{d Q}, \mathbf{d Z}, \mathbf{d F}$ Morales and Kool found that minor groove interactions are of considerable importance for DNA synthesis performed by the investigated enzyme. ${ }^{39}$ It turned out that these interactions are more important for extension than formation of the base pair.

The fact that hydrogen bonding is not required for faithful nucleotide incorporation is further supported by recent remarkable studies reported by Schultz, Romesberg and coworkers. With the aim to expand the genetic alphabet they synthesized an array of nucleotides bearing hydrophobic aromatic nucleobase surrogates that show little if any similarity to natural nucleobases. ${ }^{40}$ These analogues were subsequently tested towards their action on DNA polymerases and exhibit in some cases remarkable activity. A full coverage of all the analogues tested is certainly beyond the scope of this review. Thus, we will focus to the most interesting examples. The first promising example is the self-pairing propynylisocarbostyril analogue $63 .^{40 a}$

It was synthesized through coupling of persilylated isocarbostyril (60) to $\alpha$-chlorosugar 54 through $\mathrm{SnCl}_{4}$ promotion (Scheme 16). After iodination and subsequent coupling of propyne the toluoyl esters were cleaved to yield the nucleoside analogue 63. Standard manipulation lead to the $5^{\prime}-O$-triphosphate $\mathbf{6 4}$ and phosphoramidite building block 65 suited for solid-phase oligonucleotide synthesis.

Interestingly, Schultz and Romesberg et al. could show that the Klenow fragment is able to use $\mathbf{6 4}$ for insertion opposite another $\mathbf{6 3}$ moiety in the template strand with high efficiency and selectivity. ${ }^{40 a}$ Thus, these results confirm that DNA polymerases are able to promote efficient base pair formation in the absence of hydrogen bonding. Nevertheless, extension from the synthesized artificial base pair is significantly hampered and the development
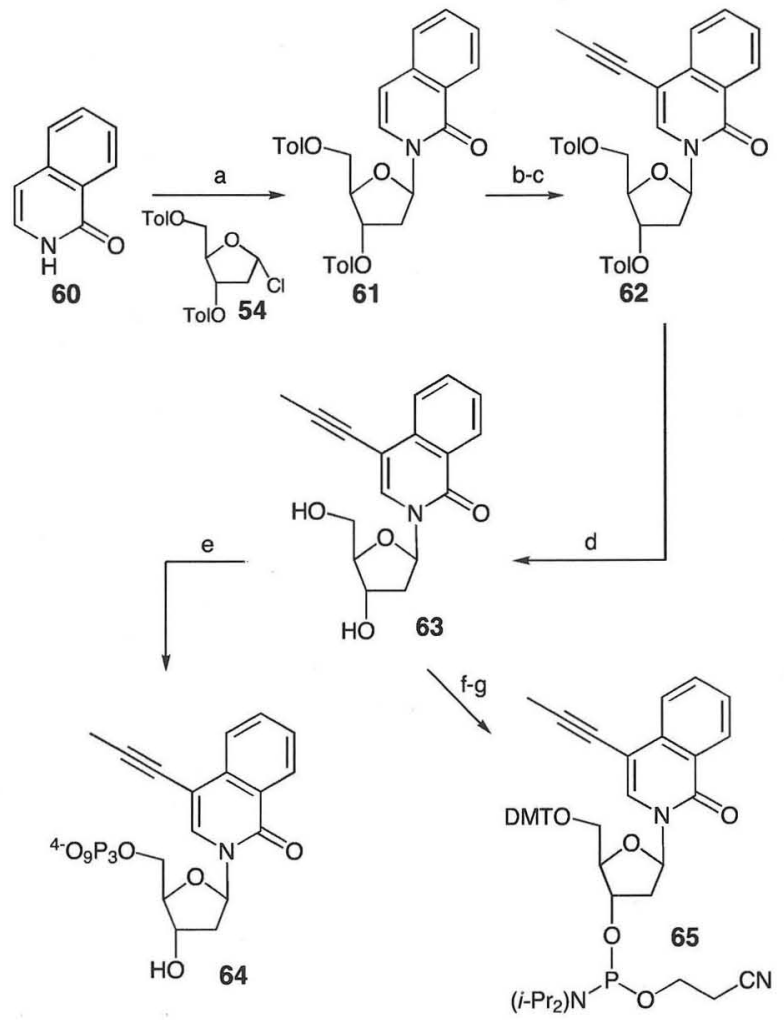

Scheme 16 a) 54, bis-TMS acetamide, then $\mathrm{SnCl}_{4}, 26 \%$; b) ICl, $\mathrm{CH}_{2} \mathrm{Cl}_{2}, 87 \%$; c) propyne, $\left(\mathrm{Ph}_{3} \mathrm{P}\right)_{2} \mathrm{PdCl}_{2}, \mathrm{CuI}, \mathrm{NEt}_{3}, 77 \%$; d) $0.4 \mathrm{M}$ $\mathrm{NaOMe}$ in $\mathrm{MeOH}$; e) $\mathrm{POCl}_{3}, \mathrm{MeO}_{3} \mathrm{PO}, 1,8$-bis(dimethylamino)naphthalene, followed by bis(tri- $n$-butylammonium) pyrophosphate, $\mathrm{DMF}, \mathrm{Bu}_{3} \mathrm{~N}, 7 \%$; f) DMTCl, DMAP, pyridine, 80\%; g) $\left(\mathrm{NCCH}_{2} \mathrm{CH}_{2} \mathrm{O}\right) \mathrm{PN}(i-\mathrm{Pr})_{2}(\mathrm{Cl})$, DIEA, $\mathrm{CH}_{2} \mathrm{Cl}_{2}, 65 \%$.

of designs that circumvent this bottleneck remain the predominant challenge toward the expansion of the genetic code. Recently, Schultz and Romesberg et al. reported first improvements along this line employing the nucleobase surrogate derived from $70 .{ }^{40 \mathrm{~b}}$ The synthesis is depicted in Scheme 17 and is reminiscent to the synthesis of 63 .

In functional DNA polymerase studies the substrates derived from 70 self-pair shows significant improvement in terms of post-incorporation extension albeit retaining high selectivity as the most potent derivative $\mathbf{6 3}$ known until then.

\subsection{Modification at the 2'-Deoxyribose Moiety}

As mentioned above, this review will only cover recent investigations on DNA polymerases that are conducted with the aim to gain insight into the mechanisms of these enzymes. Thus, in order to probe analogues bearing modified 2 -deoxyribose moieties that were tested as potential antiviral agents will not be covered.

Structural studies as well as mechanistic investigations suggest that DNA polymerases make complex interactions beyond the active site where the chemical step proceeds. Intensive enzyme functional contacts with the 


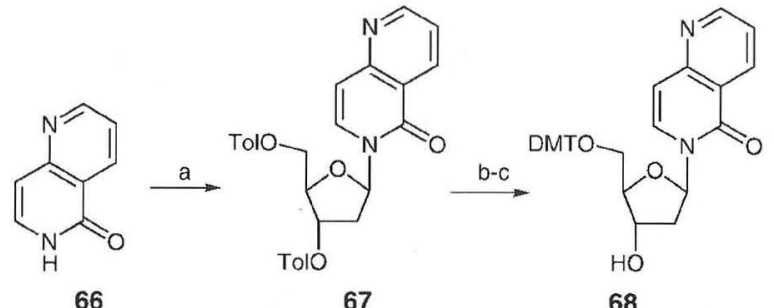

66

67

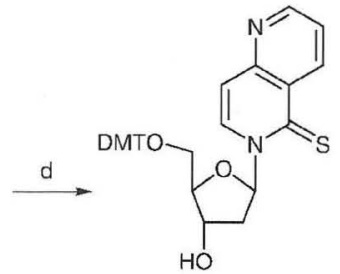

69

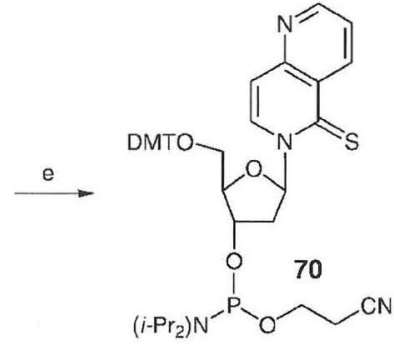

Scheme 17 a) 54, bis-TMS acetamide, then $\mathrm{SnCl}_{4}$; b) $0.5 \mathrm{M} \mathrm{NaO}$ $\mathrm{Me}, \mathrm{MeOH}$; c) DMTCl, pyridine; d) Lawesson's reagent, toluene; e) $\left(\mathrm{NCCH}_{2} \mathrm{CH}_{2} \mathrm{O}\right) \mathrm{PN}(i-\mathrm{Pr})_{2}(\mathrm{Cl})$, DIEA, $\mathrm{CH}_{2} \mathrm{Cl}_{2}$.

primer-template complex are observed. These contacts with the primer-template complex are manifold and reach up to several nucleotide pairs beyond the catalytic center, leading in most cases to a severe bent of the DNA near the primer 3'-end. These interactions primarily occur through the minor groove of the DNA duplex with the 2 '-deoxyribose-phosphodiester backbone. To monitor the interplay of HIV-1 reverse transcriptase with the primer strand substrate Giese et al. employed 4'-C-acylated thymidines $\mathbf{7 4}$ as probes (Scheme 18). ${ }^{41}$

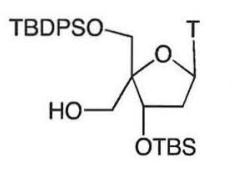

71

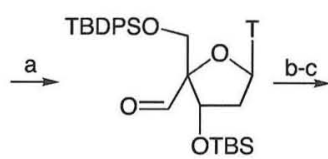

72

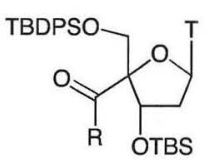

73

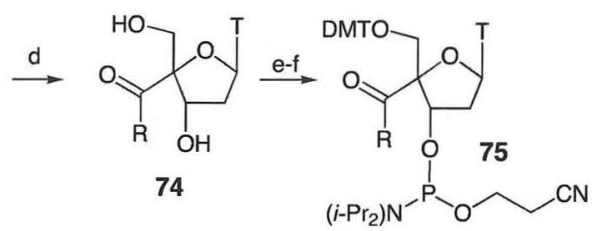

Scheme 18 a) $\left(\mathrm{Cl}_{3} \mathrm{CCO}\right)_{2} \mathrm{O}, \mathrm{DMSO}, \mathrm{Et}_{3} \mathrm{~N}, \mathrm{CH}_{2} \mathrm{Cl}_{2}, 95 \%$; b) $\mathrm{RMgX}$, THF or $t$-BuLi, $\mathrm{Et}_{2} \mathrm{O}, 63-97 \%$; c) Dess-Martin or Swern oxidation, 75-99\%; d) TBAF, THF or CsF, DMF, 18-84\%; e) DMTCl, pyridine, 80-90\%; f) $\left(\mathrm{NCCH}_{2} \mathrm{CH}_{2} \mathrm{O}\right) \mathrm{PN}(i \text {-Pr })_{2}(\mathrm{Cl})$, DIEA, $\mathrm{CH}_{2} \mathrm{Cl}_{2}, 76-92 \%$.

The synthesis of these analogues is described in Scheme 18 and commenced with compound $\mathbf{7 1}$ that was readily converted into the ketones $73 .{ }^{4 l e}$ Desilylation, $5^{\prime}$ $O$-DMT-ether formation and subsequent $3^{\prime}$-O-phosphitylation yielded the corresponding phosphoramidites $\mathbf{7 5}$ which were used for the synthesis of 4'-C-acyl containing oligonucleotides. In functional studies of HIV-1 reverse transcriptase employing 4'-C-acetylated nucleotides Giese et al. found that strand elongation along the modified residues follows at discontinuous efficiency for the first four nucleotides. ${ }^{41 \mathrm{c}}$ Interestingly, these effects correlate well with data from known structural investigations and indicate that the modification is acting like an antenna to measure steric interaction within the enzyme-substrate interplay. From an investigation of the Klenow fragment of $E$. coli DNA polymerase I it was concluded that steric hindrances are important determinants of enzymatic DNA synthesis arrest on damaged templates. ${ }^{41 \mathrm{~d}}$

To investigate the participation of steric constraints in DNA polymerases selectivity processes within the nucleotide binding pocket Marx et al. developed a functional strategy based on 4'-alkylated nucleosides as steric probes. ${ }^{42}$ Alkyl groups at the $4^{\prime}$-position were chosen to increase steric bulk at the sugar moiety but nevertheless, minimize interference with hydrogen bonding patterns, nucleobase pairing and stacking.

The syntheses commenced with the above mentioned alcohol 71 that was converted into iodid 76 by treatment with $\mathrm{I}_{2}, \mathrm{Ph}_{3} \mathrm{P}$ and imidazole (Scheme 19). ${ }^{43}$ Hydrogenation with $\mathrm{Pd} / \mathrm{C}$ in the presence of $\mathrm{Et}_{3} \mathrm{~N}$ and subsequent cleavage of the silylethers gave $4^{\prime}$-methyl-thymidine (77a). 4'-Ethylated and $4^{\prime}-i$-butylated thymidines $77 \mathrm{~b}, \mathrm{~d}$ were synthesized in high yields from easily available aldehyde 72, following sequential Wittig reaction, desilylation and subsequent reduction of the aliphatic double bond. Finally the synthesis of thymidine analogue 77c bearing a bulky $i$-propyl group adjacent to the 4 '-quarternary carbon center was accomplished from ketone $\mathbf{7 9}$, through a Wittig reaction and subsequent desilylation and hydrogenation of the aliphatic double bond. Next, nucleosides 77a-d were converted into the desired $5^{\prime}$ - $O$-triphosphates 82a-d or phosphoramidite building blocks 81a-d suitable for the synthesis of site-specifically 4'-C-alkylated oligonucleotides.

Marx et al. assumed that if sugar recognition processes are involved in DNA polymerase fidelity mechanisms 4'alkyl modifications should significantly alter their substrate properties. Based on the steric model for DNA replication selectivity mentioned above steric constrains within the active site during mismatch formation should be even more pronounced when a DNA polymerase processes the size-augmented nucleotide analogues 82a-d. Consequently, this should lead to an increased selectivity for nucleotide incorporation. Interestingly, that was indeed observed when the Klenow fragment was studied. ${ }^{42}$

To monitor steric constraints acting on the minor groove of DNA, Marx and coworkers applied the $4^{\prime}$-alkyl modifications as steric probes which continually increase in steric bulk and point at the minor groove of double stranded DNA. They investigated the Klenow fragment in its functional primer-template contacts and found differential interactions with both DNA strands. ${ }^{43}$

Recently, several remarkable reports employing nucleotide analogues bearing either expanded or contracted 2 - 


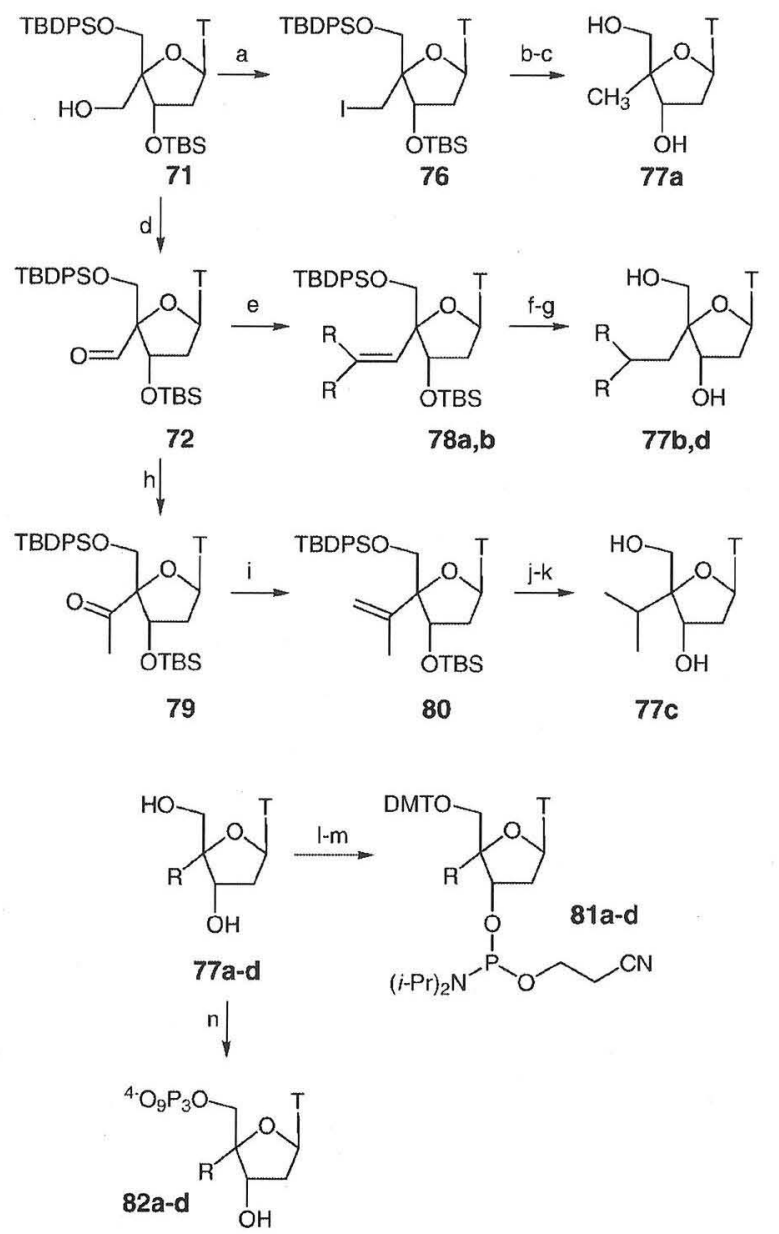

Scheme 19 a) $\mathrm{Ph}_{3} \mathrm{P}, \mathrm{I}_{2}$, imidazole, $\mathrm{C}_{6} \mathrm{H}_{6}, 85 \%$; b) $\mathrm{Pd} / \mathrm{C}, \mathrm{H}_{2}, \mathrm{EtOH}$, EtOAc, Et ${ }_{3} \mathrm{~N}$; c) TBAF, THF, $81 \%$ over two steps; d) see ref. ${ }^{41 e}$ and Scheme $18 ; \mathrm{e}) \mathrm{CH}_{3} \mathrm{PPh}_{3} \mathrm{Br}, n$-BuLi, THF or $\left(\mathrm{CH}_{3}\right)_{2} \mathrm{CHPPh}_{3} \mathrm{I}, n$-BuLi, THF, 83-99\%; f) TBAF, THF; g) Pd/C, $\mathrm{H}_{2}, \mathrm{CH}_{3} \mathrm{OH}, 88-89 \%$; h) see ref. ${ }^{4 l e}$ and Scheme 18; i) $\mathrm{CH}_{3} \mathrm{PPh}_{3} \mathrm{Br}, t$-BuOK, THF, $91 \%$; j) TBAF, THF; k) Pd/C, $\mathrm{H}_{2}$, MeOH, 99\% over two steps; l) DMTCl, pyridine, $76-88 \% ; \mathrm{m})\left(\mathrm{NCCH}_{2} \mathrm{CH}_{2} \mathrm{O}\right) \mathrm{PN}(i-\mathrm{Pr})_{2}(\mathrm{Cl})$, DIEA, $\mathrm{CH}_{2} \mathrm{Cl}_{2}, 79-96 \%$; n) $\mathrm{POCl}_{3}, \mathrm{MeO}_{3} \mathrm{PO}, 1,8$-bis(dimethylamino)naphthalene, followed by bis(tri- $n$-butylammonium) pyrophosphate, DMF, $\mathrm{Bu}_{3} \mathrm{~N}, 23-68 \%$.

deoxyribose moieties were studied on their interplay with DNA polymerases. These studies were in part intended to get insight into which parts of the sugar moiety are necessary for recognition and incorporation by DNA polymerases and to reveal the importance of sugar conformation and conformational flexibility. In this context Herdewijn at al. investigated several DNA polymerases in their interplay with anhydrohexitol nucleoside 5 '-O-triphosphates (hNTPs), analogues that have conformational similarity with ribonucleoside $5^{\prime}$ - $O$-triphosphates and bear a six-membered ring (Figure 7). ${ }^{44}$

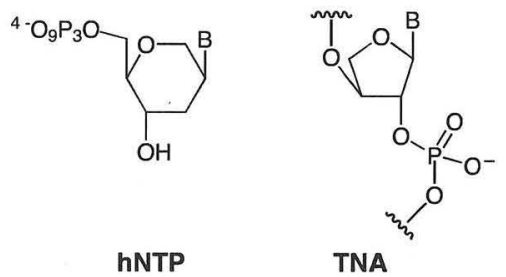

Figure 7

The synthesis was originally invented for the development of effective antisense reagents and thus, is not covered in this review. ${ }^{45}$ Herdewijn et al. were able to show that all DNA polymerases tested were able to insert the artificial hNTPs albeit extension from inserted anhydrohexitol was somehow hampered. ${ }^{44}$

In a highly interesting set of experiments Szostak et al. investigated the proficiency of several DNA polymerases to bypass threose nucleic acids (TNA), a DNA analogue especially interesting with regard to the chemical etiology of nucleic acids composed out of repeat units that are one atom shorter than that of DNA. ${ }^{46}$ As reported by Eschenmoser, TNA still possesses high binding affinity towards each other and is capable of cross-pairing to DNA and RNA. ${ }^{47}$ Szostak and coworkers found that certain DNA polymerases are able, despite the significant differences in the sugar-phosphate backbone, to copy limited stretches of a TNA template. ${ }^{46}$ The authors suggest that due to the high activity of wild-type DNA polymerases it might be possible to evolve a TNA directed DNA-polymerase with improved reactivity.

\subsection{Modification at the Phosphate Backbone}

Several very interesting studies are reported that are devoted to investigate the potential of DNA polymerases to incorporate nucleotides that have modified phosphate moieties. In order to investigate the stereochemistry of the DNA polymerase reaction one of the non-bridging oxygens at the $\alpha$-phosphate was substituted with sulfur. ${ }^{48}$ It was found that only the Sp-derivative was accepted as substrate by the Klenow fragment and Taq DNA polymerase synthesizing stereoregular Rp-phosphorthioate DNA. Most remarkable are modifications that delete charge at the backbone but nevertheless are tolerated by DNA polymerases. Thus, it has been shown that nonbridging oxygens can be replaced by a methyl group or the $\alpha$-oxygen of a triphosphate with a $\mathrm{BH}_{3}$ group and both analogues are still substrates for DNA polymerases. ${ }^{49,50}$

\section{$4 \quad$ Outlook}

Enzymatic template-directed DNA polymerization is a complex process that is intensively studied. Numerous insights in the function of these enzymes were gained through employment of chemically modified substrates. Synthetic chemists used their skills to create molecules 
that allow investigation of enzymatic features and properties that are otherwise difficult to access. For instance, through employment of chemically altered substrates in functional DNA polymerase studies it is now believed that a mere hydrogen bonding model alone as the sole driving force for fidelity of DNA polymerases can not account for the observed selectivity according to Watson-Crick. Geometric and steric effects seem to have much greater effect as originally assumed. Nevertheless, we are far from completely understanding these enzymes, which may be regarded as complex machines. To make detailed understanding even more difficult to access, DNA polymerases make complex interactions with the primer-template strands during catalysis of DNA polymerization that react far beyond the active site where the chemical step proceeds. The implication of these contacts on enzyme selectivity are not well understood. Furthermore, several new DNA polymerases that exhibit remarkable, so far unprecedented features like the ability to bypass bulky DNA lesions, that are known to be mutagenic, were discovered. As mentioned above these new enzymes show a dramatically reduced fidelity exhibiting error rates several orders of magnitude higher than the enzymes responsible for the major part of DNA synthesis in replication. The origins of the apparent variations of error propensity remain to be elucidated in the future. First insights into mechanisms of low selectivity of DNA polymerase $\eta$ were reported and comprised the use of $2^{\prime}$-deoxyguanosine analogues $53 .^{31}$ Nevertheless, we are convinced that new synthetic molecules with precisely designed new properties are needed for further progress in this exciting research field.

\section{Acknowledgment}

Our work is supported by the Volkswagen-Stiftung, Deutsche Forschungsgemeinschaft, Fonds der Chemischen Industrie, Dr. Otto Röhm Gedächtnisstiftung, and Roche Diagnostics which we gratefully acknowledge. We thank Professor Dr. M. Famulok at Bonn University for his support of our research program in the past years.

\section{References}

(1) Kornberg, A.; Baker, T. A. DNA Replication, 2nd ed.; W. H. Freeman and Company: New York, 1991.

(2) (a) Joyce, C. M.; Steitz, T. A. Annu. Rev. Biochem. 1994, 63, 777-822. (b) Steitz, T. A.; Smerdon, S. J.; Jäger, J.; Joyce, C. M. Science 1994, 266, 2022.

(3) Reviews: (a) Kool, E. T. Annu. Rev. Biochem. 2002, 71, 191. (b) Patel, P. H.; Loeb, L. A. Nat. Struct. Biol. 2001, 8, 656. (c) Kunkel, T. A.; Bebenek, K. Annu. Rev. Biochem. 2000, 69, 497. (d) Kool, E. T.; Morales, J. C.; Guckian, K. M. Angew. Chem. Int. Ed. 2000, 39, 991. (e) Kunkel, T. A.; Wilson, S. H. Nat. Struct. Biol. 1998, 5, 95.

(f) Diederichsen, U. Angew. Chem. Int. Ed. 1998, 37, 1655. (g) Goodman, M. F. Proc. Natl. Acad. Sci. U.S.A. 1997, 94, 10493. (h) Echols, H.; Goodman, M. F. Annu. Rev. Biochem. 1991, 60, 477.
(4) Reviews: (a) Goodman, M. F. Annu. Rev. Biochem. 2002, 71,17 . (b) Hübscher, U.; Maga, G.; Spadari, S. Annu. Rev. Biochem. 2002, 71, 133. (c) Marx, A.; Summerer, D. ChemBioChem 2002, 3, 405. (d) Friedberg, E. C.; Fischhaber, P. L.; Kisker, C. Cell 2001, 107, 9. (e) Livneh, Z. J. Biol. Chem. 2001, 276, 25639. (f) Goodman, M. F.; Tippin, B. Nat. Rev. Mol. Cell Biol. 2000, 1, 101. (g) Hübscher, U.; Nasheuer, H. P.; Syvaoja, J. E. Trends Biochem. Sci. 2000, 25, 143. (h) Friedberg, E. C.; Feaver, W. J.; Gerlach, V. L. Proc. Natl. Acad. Sci. U.S.A. 2000, 97, 5681. (i) Friedberg, E. C.; Gerlach, V. L. Cell 1999, 98, 413 (j) Johnson, R. E.; Washington, M. T.; Prakash, S.; Prakash, L. Proc. Natl. Acad. Sci. U.S.A. 1999, 100, 3895.

(5) (a) Johnson, S. J.; Taylor, J. S.; Beese, L. S. Proc. Natl. Acad. Sci. U.S.A. 2003, 96, 12224. (b) Silvian, L. F.; Toth, E. A.; Pham, P.; Goodman, M. F.; Ellenberger, T. Nat. Struct. Biol. 2001, 8, 984. (c) Zhou, B.-L.; Pata, J. D.; Steitz, T. A. Mol. Cells 2001, 8, 427. (d) Trincao, J.; Johnson, R. E.; Escalante, C. R.; Prakash, S.; Prakash, L.; Aggarwal, A. K. Mol. Cells 2001, 8, 417. (e) Boudsocq, H.; Ling, F.; Woodgate, R.; Yang, W. Cell 2001, 107, 91. (f) Franklin, M. C.; Wang, J.; Steitz, T. A. Cell 2001, 98, 413.

(g) Doublié, S.; Tabor, S.; Long, A. M.; Richardson, C. C.; Ellenberger, T. Nature (London, U.K.) 1998, 391, 251. (h) Korolev, Y.; Li, S.; Waksman, G. EMBO J. 1998, 17, 7514. (i) Kiefer, J. R.; Mao, C.; Braman, J. C.; Beese, L. S. Nature (London, U.K.) 1998, 391, 304. (j) Huang, H. F.; Chopra, R.; Verdine, G. L.; Harrison, S. C. Science (Washington, DC, U.S.) 1998, 282, 1669. (k) Ollis, D. L.; Brick, P.; Hamlin, R.; Xuong, N. G.; Steitz, T. A. Nature (London, U.K.) 1985, 313, 762.

(6) (a) Creighton, S.; Bloom, L. B.; Goodman, M. F. Methods Enzymol. 1995, 262, 232. (b) Goodman, M. F.; Creighton, S.; Bloom, L. B.; Petruska, J. Crit. Rev. Biochem. Mol. Biol. 1993, 28, 83 .

(7) A recent application: Harris, V. H.; Smith, C. L.; Cummins, W. J.; Hamilton, A. L.; Hornby, D. P.; Williams, D. W. Org. Biomol. Chem. 2003, 1, 2070.

(8) Hübscher, U.; Spadari, S. Physiol. Rev. 1994, 74, 259.

(9) Ichikawa, E.; Kato, K. Curr. Med. Chem. 2001, 8, 385.

(10) Thum, O.; Jäger, S.; Famulok, M. Angew. Chem. Int. Ed. 2001, 40, 3990.

(11) Recent reviews: (a) Verma, S.; Jäger, S.; Thum, O.; Famulok, M. Chem. Rec. 2003, 3, 51. (b) Bittker, J. A.; Phillips, K. J.; Liu, D. R. Curr. Opin. Chem. Biol. 2002, 6, 367.

(12) (a) Brakmann, S.; Lobermann, S. Angew. Chem. Int. Ed. 2001, 40, 1427. (b) Brakmann, S.; Nieckchen, P. ChemBioChem 2001, 2, 773. (c) Zink, D.; Cremer, T.; Saffrich, R.; Fischer, R.; Trendelenburg, M. F.; Ansorg, W.; Stelzer, E. H. K. Hum. Genet. 1998, 102, 241.

(13) (a) Switzer, C.; Moroney, S. E.; Benner, S. A. J. Am. Chem. Soc. 1989, 111, 8322. (b) Piccirilli, J. A.; Krauch, T.; Moroney, S. E.; Benner, S. A. Nature (London, U.K.) 1990 343, 103. (c) Bain, J. D.; Switzer, S. E.; Chamberlin, A. R.; Benner, S. A. Nature (London, U.K.) 1992, 356, 537.

(d) Horlacher, J.; Hottiger, M.; Podust, V. N.; Hübscher, U.; Benner, S. A. Proc. Natl. Acad. Sci. U.S.A. 1995, 92, 6329. (e) Lutz, M. J.; Held, H. A.; Hottiger, M.; Hübscher, U.; Benner, S. A. Nucleic Acids Res. 1996, 24, 1308.

(14) (a) Seela, F.; Gabler, B. Helv. Chim. Acta 1994, 77, 622. (b) Kazimierczuk, Z.; Mertens, R.; Kawczynski, W.; Seela, F. Helv. Chim. Acta 1991, 74, 1742. (c) Seela, F.; Wei, C. Helv. Chim. Acta 1997, 80, 73. (d) Seela, F.; Mertens, R.; Kazimierczuk, Z. Helv. Chim. Acta 1992, 75, 2298. 
(15) (a) Roberts, C.; Bandaru, R.; Switzer, C. J. Am. Chem. Soc. 1997, 119, 4640. (b) Roberts, C.; Bandaru, R.; Switzer, C. Tetrahedron Lett. 1995, 36, 3601.

(16) Jurczyk, S. C.; Kodra, J. T.; Park, J.-H.; Benner, S. A.; Battersby, T. R. Helv. Chim. Acta 1999, 82, 1005.

(17) Ludwig, J.; Eckstein, F. J. Org. Chem. 1989, 54, 631.

(18) See comments in ref. ${ }^{13 a}$ and ref. ${ }^{19}$.

(19) Tor, Y.; Dervan, P. B. J. Am. Chem. Soc. 1993, 115, 4461.

(20) Strazewski, P.; Tamm, C. Angew. Chem., Int. Ed. Engl. 1990, 29, 36.

(21) Charczuk, R.; Tamm, C.; Suri, B.; Bickle, T. A. Nucleic Acids Res. 1986, 14, 9530.

(22) Hirao, I.; Ohtsuki, T.; Mitsui, T.; Yokoyama, S. J. Am. Chem. Soc. 2000, 112, 6118.

(23) (a) Hsieh, H.-P.; McLaughlin, L. W. J. Org. Chem. 1995, 60, 5356. (b) Daves, G. D. Jr. Acc. Chem. Res. 1990, 23, 201.

(24) Guo, M.-J.; Hildbrand, S.; Leumann, C. J.; McLaughlin, L. W.; Waring, M. J. Nucleic Acids Res. 1998, 26, 1863.

(25) Hildbrand, S.; Leumann, C. J. Angew. Chem. Int. Ed. 1996, $35,1968$.

(26) (a) Krohn, K.; Heins, H.; Wielckens, K. J. Med.Chem. 1992, 35, 511. (b) Kraus, G. A.; Molina, M. T. J. Org. Chem. 1988, 53,752 .

(27) Fraley, A. W.; Chen, D.; Johnson, K.; McLaughlin, L. W. J. Am. Chem. Soc. 2003, 125, 616.

(28) (a) Spratt, T. E.; Campbell, C. R. Biochemistry 1994, 33 11364. (b) Spratt, T. E.; de los Santos, H. Biochemistry 1992, 31, 3688.

(29) (a) Krenitsky, T. A.; Koszalka, G. W.; Tuttle, J. V. Biochemistry 1981, 20, 3615. (b) Krenitsky, T. A.; Rideout, J. L.; Chao, E. Y.; Koszalka, G. W.; Gurney, F.; Crouch, R. C.; Cohn, N. K.; Wolberg, G.; Vinegar, R. J. Med. Chem. 1986, 29, 138

(30) Spratt, T. E. Biochemistry 2001, 40, 2647.

(31) Washington, M. T.; Wolfle, W. T.; Spratt, T. E.; Prakash, L.; Prakash, S. Proc. Natl. Acad. Sci. U.S.A. 2003, 100, 5113.

(32) Ren, R. X.-F.; Chaudhuri, N. C.; Paris, P. L.; Rumney, I. V. S.; Kool, E. T. J. Am. Chem. Soc. 1996, 118, 7671

(33) Moran, S.; Ren, R. X.-F.; Rumney, I. V. S.; Kool, E. T. J. Am. Chem. Soc. 1997, 119, 2056.

(34) Moran, S.; Ren, R. X.-F.; Kool, E. T. Proc. Natl. Acad. Sci. U.S.A. 1997, 94, 10506

(35) Morales, J. C.; Kool, E. T. Nat. Struct. Biol. 1998, 5, 950.

(36) Matray, T. J.; Kool, E. T. Nature (London, U.K.) 1999, 399, 704.

(37) Morales, J. C.; Kool, E. T. J. Am. Chem. Soc. 2000, 121, 2323.

(38) Kovács, T.; Ötvös, L. Tetrahedron Lett. 1988, 29, 4525.

(39) Morales, J. C.; Kool, E. T. J. Am. Chem. Soc. 2000, 122, 1001.

(40) (a) Matsuda, S.; Henry, A. A.; Schultz, P. G.; Romesberg, F. E. J. Am. Chem. Soc. 2003, 125, 6134. (b) Yu, C.; Henry, A. A.; Romesberg, F. E.; Schultz, P. G. Angew. Chem. Int. Ed. 2002, 41, 3841. (c) Tae, E. L.; Wu, Y.; Xia, G.; Schultz, P. G.; Romesberg, F. E. J. Am. Chem. Soc. 2001, 123, 7439. (d) Ogawa, A. K.; Wu, Y.; Berger, M.; Schultz, P. G.;
Romesberg, F. E. J. Am. Chem. Soc. 2000, 122, 8803 (e) Ogawa, A. K.; Wu, Y.; McMinn, D. L.; Liu, J.; Schultz, P. G.; Romesberg, F. E. J. Am. Chem. Soc. 2000, 122, 3274 (f) Wu, Y.; Ogawa, A. K.; Berger, M.; McMinn, D. L.; Liu J.; Schultz, P. G.; Romesberg, F. E. J. Am. Chem. Soc. 2000 122, 7621. (g) McMinn, D. L.; Ogawa, A. K.; Wu, Y.; Liu, J.; Schultz, P. G.; Romesberg, F. E. J. Am. Chem. Soc. 1999, $121,11585$.

(41) (a) Marx, A.; Spichty, M.; Amacker, M.; Schwitter, U.; Hübscher, U.; Bickle, T. A.; Maga, G.; Giese, B. Chem. Biol. 1999, 6, 111. (b) Marx, A.; Amacker, M.; Stucki, M.; Hübscher, U.; Bickle, T. A.; Giese, B. Nucleic Acids Res. 1998, 26, 4063. (c) Marx, A.; MacWilliams, M. P.; Bickle, T. A.; Schwitter, U.; Giese, B. J. Am. Chem. Soc. 1997, 119 , 1131. (d) Hess, M. T.; Schwitter, U.; Petretta, M.; Giese, B.; Naegeli, H. Biochemistry 1997, 36, 2332. (e) Marx, A. Erdmann, P.; Senn, M.; Körner, S.; Jungo, T.; Petretta, M.; Imwinkelried, P.; Dussy, A.; Kulicke, K. J.; Macko, L.; Zehnder, M.; Giese, B. Helv. Chim. Acta 1996, 79, 1980.

(42) (a) Summerer, D.; Marx, A. Angew. Chem. Int. Ed. 2001, 40, 3693. (b) Strerath, M.; Cramer, J.; Restle, T.; Marx, A. J. Am. Chem. Soc. 2002, 124, 11230. (c) Cramer, J.; Strerath, M.; Marx, A.; Restle, T. J. Biol. Chem. 2002, 277, 43593. (d) Summerer, D.; Marx, A. J. Am. Chem. Soc. 2002, 124, 910. (e) Strerath, M.; Marx, A. Angew. Chem. Int. Ed. 2002 41, 4766. (f) Strerath, M.; Summerer, D.; Marx, A. ChemBioChem 2002, 3, 578.

(43) (a) Detmer, I.; Summerer, D.; Marx, A. Chem. Commun. 2002, 2314. (b) Detmer, I.; Summerer, D.; Marx, A. Eur. J. Org. Chem. 2003, 1837.

(44) (a) Vastmans, K.; Pochet, S.; Peys, A.; Kerremans, L.; Van Aerschot, A.; Hendrix, C.; Marlière, P.; Herdewijn, P. B. Biochemistry 2000, 39, 12757. (b) Vastmans, K.; Froeyen, M.; Kerremans, L.; Pochet, S.; Herdewijn, P. B. Nucleic Acids Res. 2001, 29, 3154.

(45) De Bouvere, B.; Kerremans, L.; Rozenski, J.; Janssen, G.; Van Aerschot, A.; Claes, P.; Busson, R.; Herdewijn, P. B. Liebig Ann. Recl. 1997, 1453.

(46) (a) Chaput, J. C.; Ichida, J. K.; Szostak, J. W. J. Am. Chem. Soc. 2003, 125, 856. (b) Chaput, J. C.; Szostak, J. W. J. Am. Chem. Soc. 2003, 125, 9274.

(47) Schöning, K.-U.; Scholz, P.; Guntha, S.; Wu, X.; Krishnamurthy, R.; Eschenmoser, A. Science 2000, 290, 1347.

(48) (a) Burgers, P. M. J.; Eckstein, F. J. Biol. Chem. 1979, 254 6889. (b) Brody, R. S.; Frey, P. A. Biochemistry 1981, 20, 1245 .

(49) (a) Alexandrova, L. A.; Skoblov, A. Y.; Jasko, M. V.; Victorova, L. S.; Krayevsky, A. A. Nucleic Acids Res. 1998 26, 778. (b) Dineva, M. A.; Chakurov, S.; Bratovanova, E. K.; Devedjiev, I.; Petkov, D. D. Bioorg. Med. Chem. 1993, 1,411 .

(50) (a) He, K.; Porter, K. W.; Hasan, A.; Briley, J. D.; Shaw, B R. Nucleic Acids Res. 1999, 27, 1788. (b) Li, H.; Porter, K. Huang, F.; Shaw, B. R. Nucleic Acids Res. 1995, 23, 4495. 